\title{
The sustainability of woody biomass feedstock production and landscape management: land use, phytoremediation, biodiversity, and wildlife habitats
}

\author{
Sándor Némethy ${ }^{1,2,3}$ and László Szemethy ${ }^{2}$ \\ ${ }^{1}$ University of Gothenburg, Department of Conservation, Sweden; ${ }^{2}$ University of Pécs, Institute of Regional Development, \\ Hungary; ${ }^{3}$ Eszterházy Károly University, Eger, Károly Róbert Campus, Gyöngyös, Hungary \\ Email addresses: sandor@conservation.gu.se; laszlo.szemethy@gmail.com
}

\begin{abstract}
Woody biomass feedstock is suitable for direct combustion, gasification, pyrolysis, ethanol or methanol production yielding heat, charcoal, pyrolysis oil, green electricity and bio-propellants. There are several issues concerning the environmental, socio-cultural and economic sustainability of woody biomass production connected to land use, protection and/or creation of wildlife habitats, conservation and remediation of wastelands and derelict cultural landscapes. Establishing energy plantations on arable lands or on grasslands is against nature conservation, while setting up them in depleted agricultural lands of inferior quality, polluted areas or wastelands could be advantageous for land reclamation and wildlife, because of

- root filtration, phytoremediation, less chemicals and improved soils;

- possibilities to establish organic production by combining irrigation with biologically cleaned, pathogen-free wastewater;

- application of biosolids for fertilization connected to short rotation forestry (SRF) or short rotation coppicing (SRC), agroforestry (AF) or polycyclic arboriculture;

- more permanent cover that provides shelter and biomass for feeding, which is especially important in winter;

- higher architectural complexity of vegetation provides more place for nesting and feeding;

- forbs in the undergrowth and young shots could provide better quality food for wildlife than the intensive monocultures. Biomass production is very complex and includes a vast variety of feedstocks suitable for a range of energy production technologies and many other products depending on the species and the conditions of cultivation. Therefore, the solution is a complex management system, including land use, phytoremediation, solid waste and wastewater management and ecosystembased planning combined with other renewable energy sources such as geothermal energy, solar cells, wind turbines, hydroelectric power plants and non-polluting high-tech waste incinerators in one dynamic system.
\end{abstract}

Keywords - biomass production, phytoremediation, biodiversity, wildlife habitats, agroforestry, short rotation forestry (SRF), short rotation coppicing (SRC), Persistent Organic Pollutants (POPs)

Received: August 8, 2019

Accepted: August 21, 2019

\section{Introduction}

The discovery, production and sustainable use of renewable energy sources is a much more complex problem than simply meeting the short-term energy needs of humankind, because it involves ecological and economic consequences for the cultural landscapes and ecosystem services concerned. Energy production and use are realized at several levels: we can talk about local, regional, national and global energy systems and their location in natural terrestrial systems linked to biogeochemical cycles, which are often altered by human activities. The production and use of renewable energy (with particular emphasis on bioenergy, solar power, hydroelectric power, wind and geothermal energy) is the key for all aspects of sustainability, including long-term economic viability, which is strongly connected to the sustainable use of ecosystem services.

Agricultural lands occupy $37.4 \%$ of the earth's land surface. Agriculture and agriculture-related activities account for $44.4 \%$ of methane and $70 \%$ of global anthropogenic nitrous oxide emissions. One of the possible most promising ways to reduce these greenhouse gases is the substitution of fossil fuels for energy production by agricultural feedstocks (e.g. crop residues, dung and dedicated energy crops). In agriculture it is possible to establish combined production structures, which include organic, chemical-free crop production, the use of bio-energy plantations and other 
dedicated energy crops as biological filters, the application of biologically cleaned waste water, free from heavy metals, as crop nutrient through irrigation and the use of waste water sludge and fermentable organic waste for production of biogas and, if sufficiently purified, biosolids as plant nutrients. Dedicated bio energy crops may increase the soil carbon sequestration, hereby contributing to the reduction of global warming (McCalmont et.al. 2017). In this way complete ecological cycles can be created, which utilize all energy sources in an optimal way and minimize solid waste production. The economics, environmental impact and the social acceptance of the practical aspects of ecosystem approach are indispensable for the energy management of these different scales of energy systems and must be taken into consideration when planning regional development projects.

Bioenergetics plays an important role in the circular economy that forms the basis of a sustainable society, based on the renewable energy - finished product/service - zero waste system and sustainable use of ecosystem services. The operation of this system is ensured by the environmentally conscious production of commodities based on life cycle assessment (LCA), waste management focusing on recycling and waste to energy programs. It is important to take into consideration the principle of plurality in the use of renewable energies, which requires the complementary use of these types of energy not only for economic but also for environmental and energy security reasons (Sovacool and Murkherjee, 2011; Némethy, 2018). Bioenergy itself is diverse and closely linked to agriculture, forestry, wastewater treatment, energy recovery from solid waste and industries (waste heat) and services producing organic, compostable waste. Biomass supplies an increasing share of electricity and heat and continues to provide the majority of heating produced with renewable sources. Trends include increasing consumption of solid biomass pellets (for heat and power) and use of biomass in combined heat and power (CHP) plants and in centralized district heating systems. Due to the aforementioned complexity and limitations of bioenergetics, biomass production should be combined with other renewable energy sources such as geothermal energy, solar cells, wind turbines, hydroelectric power plants and nonpolluting high-tech waste incinerators in one system (International Energy Agency, 2018; Némethy, 2018). It can also be the key to solving the "energy trilemma".

Shortage of natural wood is a common problem in different countries - particularly for forest industries in developed countries and for fuel in developing countries. The agricultural expansion of the last decades resulted in deforestation and forest degradation and the illusion of economic development, seemingly benefiting billions of people in a short term and causing severe environmental and social problems for future generations. The rapid expansion of agriculture for food, fuel and other products has resulted in significant greenhouse gas (GHG) emissions. An estimated 414 per cent of global GHG emissions are associated with deforestation and degradation, making agriculture a major component of the human factors of global climate change mitigation efforts (Vermeulen et al. 2012). It is therefore critical that we fully understand the relationship between the development of the agricultural sector and its impact on forests and propose appropriate integrated solutions, where forests are protected and used sustainably, traditionally managed high quality forests are not replaced by intensive bioenergy plantations, energy feedstocks are not cultivated on land, which is most suitable for food production and renewable energy systems are integrated into one holistic management concept, based on interlinked natural and anthropogenic ecological cycle processes (Fig. 2). It is important to emphasize, that forestry and plantations of woody energy feedstocks represent different ways of using ecosystem services, different land use systems, and the management of woody bioenergy plantations is not traditional forestry. Forestry is a much more complex system of natural resource management including the provision of timber, fuel wood and wood for paper, wildlife habitat, watershed and natural water quality management, conservation of landscapes and biodiversity, erosion control, preservation of forests as "sinks" for atmospheric carbon dioxide and even recreation and even sustainable tourism. There are several cultivation methods for woody bioenergy feedstocks, where the proportion of additional benefits (firewood, raw material for crafts, land reclamation, provision of wildlife habitats, food and even cosmetic products ) varies, and the characters of plantations show different degrees of similarity to natural forests in terms of biodiversity and the number of ecological niches: short rotation coppicing (SRC), short rotation forestry (SRF), agroforestry (AF) and polycyclic arboriculture will be discussed later in this study. The most intensive method is short rotation coppicing (SRC), which is ecologically closer akin to arable farming than to conventional forestry and often monocultural. Even if biodiversity might be greater in these plantations than in intensive arable farming, the main purpose is production of bioenergy and the ecological sustainability of "bioenergy farming" greatly depends on the cultivation methods, including fertilization, irrigation, pest management and the length of rotation cycles. Fast growing woody bioenergy plantations can produce large quantities of biomass in a short time. The raw material produced is suitable for direct combustion, gasification, pyrolysis, ethanol or methanol production yielding heat, charcoal, pyrolysis oil (biocrude), green electricity and bio-propellants.

Obviously, from the point of view of climate change the key factor is that growing biomass absorbs the carbon dioxide from the atmosphere and releases it again when it is burnt, but within a short time - this is the fast spinning biological carbon cycle. Regardless of the actual potential, biomass resources must be produced, harvested/collected, transported, stored, and processed based on new paradigms associated with input costs, production schedules, capacities and capabilities. The challenge for researchers, producers, equipment manufacturers, and end users will be to incorporate production systems that are sustainable and efficient, using existing systems when appropriate. In addition, improvements in the conversion - biochemical, physicochemical, and thermo-chemical - of ligno-cellulosic biomass 
to biofuels must rapidly progress within the next ten years to meet biofuel production goals.

A critical element in the ultimate success of biofuel production will be the linkage between biomass feedstock development, production, harvesting, transporting, storing, and processing into biofuels/bioproducts and/or energy. Another important factor about biomass energy from FAO's point of view is that it creates a lot of jobs. By creating or improving rural infrastructure, it opens new opportunities. Also, it has a tremendous potential for rehabilitating degraded land, since several plant species are suitable for phytoremediation and that plant, if it's used for energy, has an added value. It makes land reclamation economically more viable.

In a holistic and integrated food and energy system there is no conflict between bio energy production and food supply and the ecological footprint is sufficiently small. A transition is needed from fossil fuel centred, ineffective and inefficient societies to the ecologically and economically viable, recycling society. Technological developments (in conversion, as well as long-distance biomass supply chains such as those involving intercontinental transport of biomassderived energy carriers) can dramatically improve competitiveness and efficiency of bioenergy (Hamelinck et al. 2004; Faaij 2006).

\section{Short Rotation Forestry (SRF), Short Rotation Coppicing (SRC) and agroforestry: agriculture or forestry? - Issues of land use, biodiversity and landscape conservation.}

Woody biomass production can be established in different forms, but not all of them can be considered as fully ecological structures, since their impact on ecosystem services, habitats and landscape structure are very different depending on the tree species, climate, cultivation method and biodiversity:

1. Short Rotation plantations with 2-3 and 5-6 yr. rotation coppicing cycle, producing assortments for multiple industrial uses;

a. Short Rotation Forestry

b. Short Rotation Coppicing

2. New agroforestry systems with a modern complementarity between trees outside forest and agricultural activities, balancing food and wood security with environmental preservation;

3. Polycyclic arboriculture, i.e. combining tree species with different cultivation cycles, coexisting in the same plantation area.

These opportunities offered by the new cultural models need a more coordinated political and industrial organization of the wood production sector.

\section{Short Rotation Forestry}

Short-rotation forestry (SRF) is a fast-expanding sustainable silvicultural practice where high-density plantations of fastgrowing tree species produce woody biomass preferably on low quality agricultural land less suitable for food production or on fertile but degraded forest soils. In short rotation forestry systems trees are cut when they reached a size of typically $10-20 \mathrm{~cm}$ diameter at breast height, which usually takes between 8 and 20 years depending on the tree species and growing conditions. While short rotation coppicing (SRC) cuts the tree back to a stool to promote the growth of multiple stems, on a regular cycle of roughly 2-4 years or sometimes every year, short rotation forestry makes it possible to practice something more closely akin to conventional forestry, though on a shorter timescale (Facciotto et.al. 2014). Thus, the timescale of wood production is between SRC and conventional forestry, which has several ecological advantages, even if the rate of shortterm biomass production is lower, than in even more intensive SRC systems. This has the effect of retaining the high productivity of a young plantation but increasing the wood to bark ratio. Applying similar techniques to sustainable conventional forestry practices, it is currently proposed that only the stem wood would be removed from the site, while the bark stripped during harvesting together with other residues should be left on site to return nutrients to the soil in order to mitigate soil-depletion. Greater attention to shortrotation forestry could offer a way to provide forest industries with enough wood resources and people in the developing world with enough fuel, while conserving natural forests (Christersson, 2005).

\section{Short Rotation Coppicing}

Fast-growing tree species can be cut down to a low stump (or stool) when they are dormant in winter and start producing many new shoots in the following growing season. Short Rotation Coppicing (SRC) is an intensive and well controlled cultivation method for production of woody biomass and has a rotation period about 25 years and with an annual woody production of at least 10 tonnes of dry matter or $25 \mathrm{~m}^{3}$ per hectare, depending on the species and growing conditions. This system has been developed to provide large-scale biomass production instead of conventional forestry, where due to economic and ecological difficulties in creating optimal water and nutrient conditions, competition from herbaceous plants and other tree species and biotic and abiotic damage are serious threats for the entire growth. Therefore, the biomass producing potential of conventional forestry is not sufficiently utilized, because the main goal is the production of industrial wood for building, furniture and fibre. Therefore, classical forestry does not focus on biomass, but on the quality of tree specimens, and tries to produce clear, cylindrical and straight trunks, because it has a much higher value than firewood. (Therefore, an important problem is the game damage of wood quality, where the achievement of this desired shape is often prevented by wild chewing. Branches, "bumps" are formed in which the biomass may be higher, but the market value of the individual tree trunks is lower.) Many species and varieties are suitable for providing biomass for energy purposes, but in practice, few species can be selected for the establishment of SRC energy plantations. The main criteria for bioenergy plants include high rate of growth, good frost tolerance, simple and economical reproducibility, high adaptability, disease-resistance to pests and easy harvesting. The three most successfully used trees for SRC systems are willow (Salix sp.), poplar (Populus sp.) 
and black locust (Robinia pseudo-acacia L.); other trees include alder (Alnus sp.), ash (Fraxinus sp.), birch (Betula sp.), and sugar maple (Acer saccharinum) and, on warmer latitudes, even eucalyptus (Eucalyptus $s p$.).

Willow (Salix sp.) is the most commonly used tree in SRC plantations for energy in Europe due to a number of advantageous properties such as fast growth and high yields, suitability for coppicing, wide tolerance of soil $\mathrm{pH}$ and structure ( $\mathrm{pH}$ 5-7.5, from heavy clays to lighter soils), tolerance of highly anoxic (waterlogged) conditions and elevated nutrient and heavy metal concentrations (suitability for phytoremediation). Willow requires humid conditions and grows best in cool-temperate climate, but there are clones suitable for warmer climate conditions as well in Eastern and Central Europe.

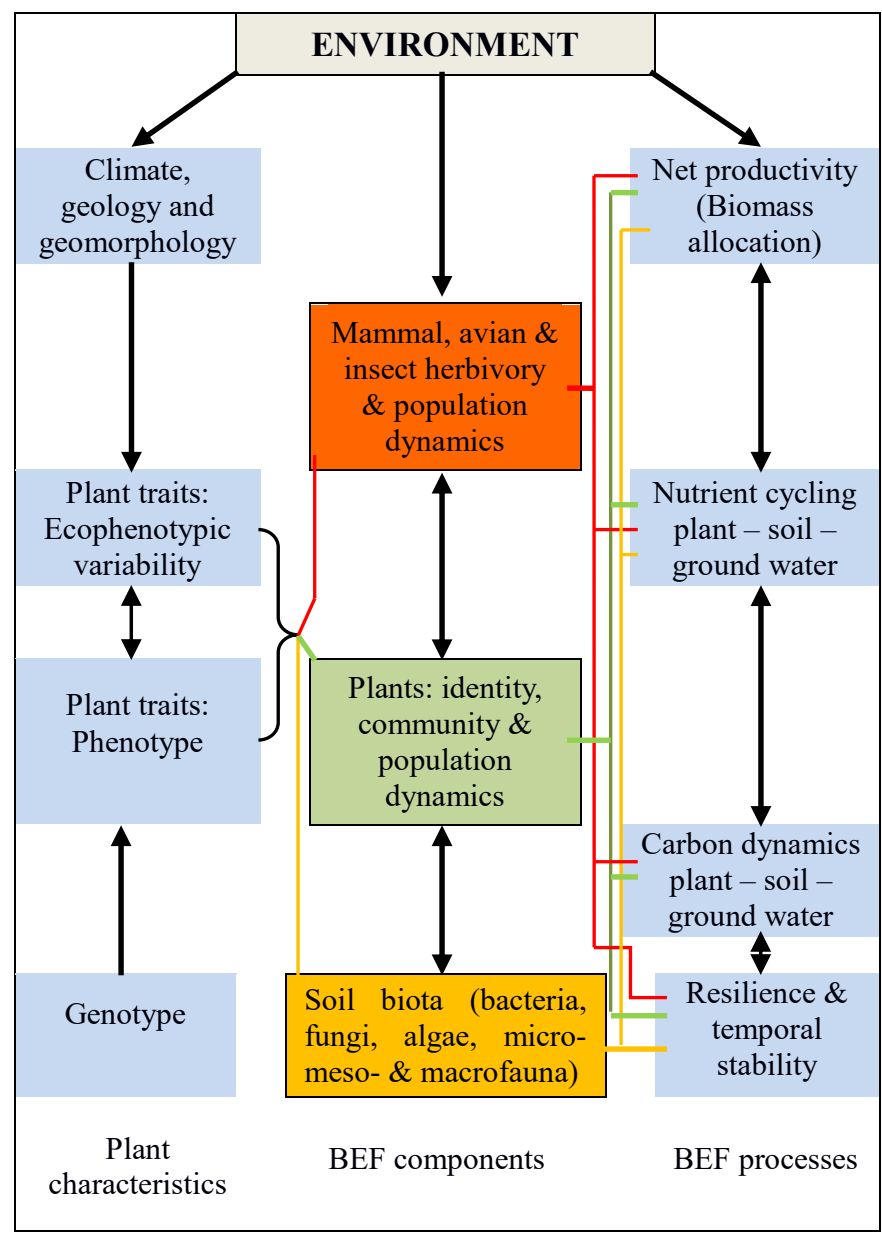

Figure 1. The most important relationships between plant traits and the biodiversity-ecosystem function (BEF) components and processes based on willow short-rotation coppice (SRC) systems. The BEF components are intimately connected to growth and productivity (green); mammal, avian and insect herbivory (above ground trophic interaction, red), and soil biota representing below ground trophic interactions (yellow). Source: redrawn and modified after Weih et.al. 2019.

Due to its wide ecological tolerance, ecophenotypic variability, large number of available species and clones, fast growth, and tolerance of environmental stress and certain similarities to grassland systems, willow SRC systems are suitable structures to apply the biodiversity-ecosystem function (BEF) theory (Weih et.al. 2019), which often lacks a sound understanding and comprehensive interpretation of the complex mechanisms behind the observed patterns of diversity-productivity relationships. It is important to take into consideration the complete set of factors within each category of BEF components (Fig. 1). According to the biodiversity-ecosystem function (BEF) theory, levels of ecosystem functions (e.g., productivity, nutrient cycling, decomposition) and the stability of those functions depend directly on all levels of biodiversity, including diversity of all biota at the level of genotypes, species, and functional groups, which are considered as sets of physiologically or morphologically similar species. Ecosystem functions are conceived as a subset of ecological processes and ecosystem structures, which are typically estimated from measures of stocks such as plant biomass or crop nutrients, in response to vascular plant diversity.

Poplar (Populus sp.) is the second most important woody plant grown for bioenergy in Europe. Its ecological preferences are different from willow, including areas with milder climates (e.g. Central and Southern Europe), sandier and drier soils due to lower water needs of poplar than willow. Their shoot system is differentiated. The growth of long shoots is continuous throughout the vegetation period. Poplars bloom early, well before budding; wind pollinators. Their fruits develop rapidly, ripening 3-6 weeks after flowering. Due to the white cotton wool - like flyers, the seeds are able to spread on large areas by the wind. The flyer detaches itself from the seed soon after it has landed. On uncovered soil, in a humid environment, some species germinate within 1-2 days. About 35 species are known, which belong to the deciduous vegetation of the northern temperate zone. Despite the small number of species, it is a highly differentiated genus both morphologically and ecologically. Most poplars are fast growing pioneer species in the temperate regions and the arid regions of the subtropics, which mainly grow on the alluvial soils of riverbeds, flood plains and deltas. Diploid genus. Close-range species are easily crossed and, therefore so many natural and artificial hybrids are known, that identification may be extremely difficult in many cases. The most widely cultivated noble poplar varieties are $P$. deltoides, $P$. nigra, $P$. deltoides x $P$. nigra hybrids, $P$. deltoides $\mathrm{x} P$. trichocarpa hybrids. Poplar plantations are less dense, and the rotation periods are substantially longer $(4-6$ or $10-15$ years) than for the willow SRC systems.

Black locust (Robinia pseudoacacia L.), originating from eastern United States, was introduced to Europe during the $17^{\text {th }}$ century first as ornamental tree but later conquered vast areas by extensive plantations for timber production and by natural propagation mostly in central and south-eastern parts of Europe. Black locust is quite drought-resistant, nitrogen fixing, able to grow on bare soils under extreme conditions, which makes it ideal for soil regeneration and reclaiming former mining sites. It is fast-growing with good coppice 
ability after harvest, and its high wood density makes it very useful as SRC for bioenergy production. Even if black locust has invasive properties, large forest areas were established in central Europe (mainly in Hungary but also in other countries such as in Italy and Poland) and the interest is increasing for Robinia SRC on agricultural land, especially in areas where land reclamation is required. In view of the recently emerging debate regarding the invasive character of Black locust, its multi-purpose use must be emphasized, particularly as bioenergy feedstock, raw material for pulp, as melliferous tree, an important plant for phytoremediation of both heavy metals and Polycyclic Aromatic Hydrocarbons (PAHs), soil improvement due to its nitrogen fixing ability, and even as a natural habitat - cover for wildlife, browse for deer, and nesting places for birds. The economic viability of biomass production by black locust has been debated many times (particularly in Short Rotation Coppice (SRC) systems), but established in a multi-purpose, ecocycle-based agricultural system where its invasive character is carefully controlled and its usefulness is fully utilized (applying even clone selection for site-adaptation and best possible performance), both environmental sustainability and profitability should be guaranteed.

Eucalyptus is a genus of fast-growing tree species originated from Australia, which contains more than 700 species. Eucalyptus is the most widely planted hardwood genus in the world, covering more than 19 million hectares, with growth rates that usually exceed $35 \mathrm{~m}^{3} \mathrm{ha}^{-1}$ year $^{-1}$ (Albaugh et.al. 2013; Stape et.al. 2001; Binkley and Stape, 2004). This tree has been extensively planted in southern Europe and, despite its high water requirements, even in the water-scarce country of South Africa $(515,000$ hectares) for timber, pulp, paper and biomass production (for SRC most often used species are $E$. gundal, E. gunnii, E. dalrympleana, and E. camaldulensis). To improve the water use efficiency of Eucalyptus new clones are being tested for environments of water shortage, since certain eucalypt clones show fast growth and low water use (Albaugh et.al. 2013). The high production of wood biomass of eucalypt is gaining interest not only in Southern Europe, but also in higher latitudes e.g. in the UK and Ireland, where more cold-tolerant clones (E. gunnii and E. nitens) are being cultivated. Eucalyptus SRC plantations are traditionally planted in single-stem plantations in $3 \times 3 \mathrm{~m}$ distances (or similar) and harvested after 7-12 years for pulp production, but in some cases, particularly for energy feedstock, very short rotation of $2-4$ years is applied, which resemble the willow coppice systems.

\section{Agroforestry}

Agroforestry is a complex land-use system in which woody perennials are deliberately integrated with crops and/or livestock on the same land-management unit either in a spatial mixture or in a temporal sequence. There are both ecological and economic interactions between the woody and non-woody components in agroforestry, which is based on four key features: competition, complexity, profitability and sustainability. "Agroforestry is a dynamic, ecologically based, natural resource management system that, through the integration of trees in farm- and rangeland, diversifies and sustains smallholder production for increased social, economic and environmental benefits" (Leakey, 1996). Agroforestry practices can be divided into two groups - those that are sequential, such as fallows, and those that are simultaneous, such as alley-cropping (Cooper et.al., 1996). The sustainable management of the competition between trees and crops for light, water and nutrients is the plantphysiological determinant of successful agroforestry systems. Simultaneous agroforestry systems are more susceptible to competition than sequential ones.

In agroforestry systems the requirement of fast growth is slightly less important than in SRC systems and this allows a greater diversity of trees and the non-woody components. This is particularly important regarding the functions of agroforestry and the possibilities to create new habitats and maintain or increase the biodiversity of agroecosystems. Using indigenous trees with high-value products in agroforestry systems enhances profitability, particularly those that can be marketed as ingredients of several finished products. In certain countries, the use of indigenous tree species is difficult, since their growth is far behind the growth of some exotic genera, such as Eucalyptus, which is extensively planted in Southern Europe and South Africa (Figure 2).

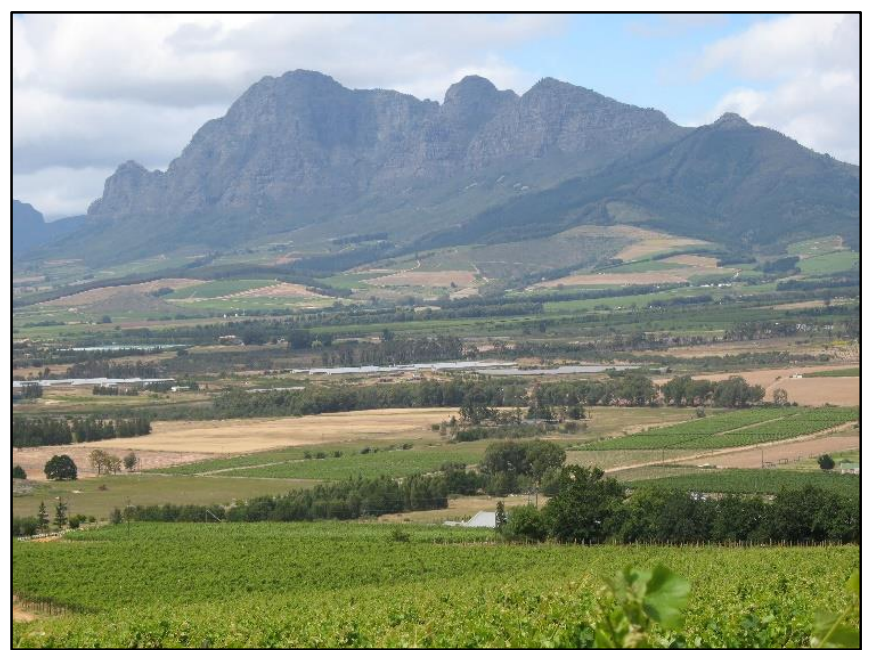

Figure 2. Agroforestry in South Africa is often dominated by eucalypts and even Mediterranean pines (Pinus pinaster), where cultivated lands (here viticulture) are surrounded by forested areas of different sizes. Photo: Sándor Némethy

\section{Polycyclic arboriculture - permanent polycyclic tree farms} The advantages of these artificial forests compared to intensive poplar plantations, address not only to technicians, farmers and ordinary citizens, but also and above all regional and national political decision makers, who could focus on the development of these plantations that combine wood production and environmental improvement. These mixed plantation methods with poplar clones and other valuable broadleaved species have been implemented both in tree farming plantations and in agroforestry systems (Facciotto et.al. 2014). This type of tree farming is called "polycyclic plantation", contain main crop trees, with different cultivation cycles, coexisting in the same plantation area with (a) very 
short rotation trees for biomass production (SRCs); (b) short rotation trees for veneer production (poplar clones); (c) medium long rotation trees for timber and high quality veneer production (walnut and other valuable broadleaved species). Higher biodiversity and species composition make polycyclic plantations more resistant to environmental stress and less demanding in terms of energetic input, they are innovative, and more sustainable than monocultures. Furthermore, due to their polycyclic rotation systems, multiple use and the number of environmental and economic benefits they provide, the short-term economic loss in biomass production are sufficiently compensated by a range of other valuable products (timber, veneer, walnut, honey, fragrance oils, etc.).

The landscape and ecosystem approach in rural planning: a holistic management concept integrating woody biomass production and environmental management ecological, economic and social implications

There are several issues concerning the environmental, sociocultural and economic sustainability of woody biomass production connected to land use, protection and/or creation of wildlife habitats, conservation and remediation of wastelands and derelict cultural landscapes. These problems include the land use where biomass production is established instead of cultivating agricultural crops for food, the limited suitability of short rotation coppice (SCR) plantations as wildlife habitats and alteration of the structure and appearance of cultural landscapes (Némethy and Walas, 2015). While woody bioenergy plantations and some perennial feedstocks can improve soil quality and biodiversity, reduce greenhouse gas emissions and improve water quality, some large-scale industrial models of modern biofuel production can negatively impact ecosystem services through the excessive use of synthetic fertilizers and agrochemicals, grassland conversion and deforestation (Pacheco et al. 2012). Particularly serious concerns were raised concerning food security, especially in regions with widespread poverty, political uncertainty, and fragile agricultural systems, which are likely to be exacerbated with accelerating climate change (Brown and Funk 2008). However, the right choice of bioenergy crops, the territory of cultivation and cultivation methods might counteract the harmful environmental and social effects of monoculture, particularly if connected to phytoremediation and soil improvement programmes often creating new employment opportunities. A number of studies have demonstrated, that there is considerable potential for increasing economically and ecologically viable bioenergy production even further, to meet a substantial fraction of future energy needs without compromising any aspect of sustainability (Smeets et.al. 2007; Somerville et al. 2010). Thus, bioenergy development may offer developing countries many advantages, ranging from energy security to poverty reduction, infrastructure development and economic growth.

Natural wastewater cleaning and irrigation with biologically cleaned wastewater

Short rotation forests, short rotation coppice plantations and even agroforestry are excellent objects for natural wastewater cleaning. Agricultural deployment of wastewater for irrigation is based on the value of its constituents, which are used as fertilizers. However, crop irrigation with insufficiently treated wastewater may result in health risks. Use of untreated sewage effluent for irrigation exposes the public to the dangers of infection with a variety of pathogens such as protozoa, bacteria and viruses. Thus, the benefit of wastewater reuse is limited by its potential health hazards associated with the transmission of pathogenic organisms from the irrigated soil to crops, to grazing animals and humans (Gupta et al., 2009; Qadir et al., 2010). Wastewater should satisfy some quality indicators as chemical structure, availability of gases, content of organic substances and bacteria, muddiness, temperature, etc. Those indicators depend on salt tolerance of the cultivated crops, chemical structure and water permeability of the soil, drainage of the ground, characteristics of the rainfalls, background content of heavy metals, meteorological and hydro-geological circumstances, irrigation technology, applied agricultural techniques, etc. The suitability of the treated water for irrigation can be determined on the basis of results from chemical analyses, vegetation and field experiments, as well as comparing various crops irrigated with clean and treated wastewater during a longer period of time (Panoras et al. 1998, 2003). Thus, biologically cleaned and recycled wastewater is a substantial nutrient resource for organic farming.

Utilization of short-rotation forests as vegetation filters for waste products is strongly supported in Sweden (Perttu and Obarska-Pempkowiak 1998; Dimitriou and Aronsson, 2004). After biological cleaning, a simple sand filter system or other particle filters can remove particles - if needed - and low concentration of disinfectants will assure the appropriate water quality. This water should be almost entirely free of bacteria and can be used for irrigation. For the safety of public health and the protection of groundwater and surface watercourses and natural habitats the environmental legislation in all developed countries require the thorough control and environmental consequence analysis as well as the systematic monitoring of the re-use of partially cleaned wastewater, which together with natural mineral-based soil improvement substances (Némethy, 2019) can maintain bio energy plantations without any other artificial fertilizers. Furthermore, the potential for phytoremediation should be taken into consideration, since waste products can also contain polluting heavy metals and organic pollutants, which some willow and poplar clones are able to absorb efficiently. When wood from this type of plantation is burned, heavy metals can be extracted from the fly ash and bottom ash. However, this process is not yet economical, so today most of the ashes are deposited at safe city waste disposal sites.

\section{Phytoremediation with woody plants combined with biomass production for energy}

Phytoremediation is a fast developing and expanding environmental technology for contaminated soils, groundwater, and wastewater that is both low-tech and lowcost, defined as the engineered use of green plants (including grasses, forbs, and woody species) to remove, contain, or 
render harmless environmental contaminants such as heavy metals, trace elements, organic compounds, persistent organic pollutants (POPs) and radioactive compounds in soil surface waters and groundwater (Watanabe, 1997). There are several phytoremediation techniques with variable effectiveness depending on the biochemical and physiological properties of the plant and the pollutant. Phytodegradation also known as phytotransformation, when pollutants or complexes are broken down to simple compounds and then transferred into the plant tissue, is the most effective technique against organic contaminants, including certain POPs (Watanabe, 1977), while phytoextraction and phytostabilisation are best suited to remove inorganic pollutants (e.g. heavy metals) but might be effective even for POPs (Gyulai et.al. 2014). Phytovolatilization, a process, in which plants take up contaminants from soil and release them as volatile form into the atmosphere through transpiration, and rhizofiltration, a technique of utilizing plant roots to absorb, concentrate, and precipitate pollutants (often toxic metals) from ground water or polluted effluents, are effective both with inorganic and even organic contaminants. Furthermore, the safe use of transgenic plants might be possible for detoxification of organic pollutants (Merino et.al. 2008). Thus, phytoremediation technologies involve processes, which are able to isolate, destroy, transport, and remove organic and inorganic pollutants from contaminated media (Echereme et.al. 2018).

Heavy metals constitute serious environmental and health hazards for plants, animals and humans. Environmental regeneration of post-industrial landscapes frequently involves reforestation and planting of trees suitable for biomass production, provided that these species possess sufficient tolerance to heavy metal contaminated soils. Recent research showed, that yields of Salix, Populus and Alnus were economically viable, showing that short-rotation coppice has a potentially valuable role in community forestry and woody biomass production is compatible with managing residual trace element contamination in brownfield soils. Research on hybrid poplars has demonstrated their ability to take up and effectively degrade organic contaminants including atrazine, 1,4-dioxane, TNT and trichloroethylene, some transgenic poplar clones showed increased capacity for phytoextraction of certain POPs such as Paraquat (Gyulai et.al. 2014; Echereme et.al. 2018), while willow has been extensively used for heavy metals (Gomes, 2012). The Salicaceae family, which includes poplar and willow trees, has been very successful in phytoremediation efforts involving chlorinated solvents such as trichloroethylene (TCE). The biomass produced in phytoremediation can be used for bioenergy production (biogas, biofuels and combustion), providing other environmental benefits such as erosion control, improving soil quality and functionality, and wildlife habitat.

\section{Biodiversity and development of wildlife habitats}

According to quite recent field experiments, species abundance in SRC plantations can be more heterogeneous than in arable lands and therefore, SRC plantations form novel habitats leading to different plant species composition compared to conventional land uses. Their landscape-scale value for biodiversity changes depending on harvest cycles and over time. As a structural landscape element, SRC plantations may positively contribute to biodiversity in rural areas, especially in land use mosaics where these plantations are admixed to other land uses with dissimilar plant species composition such as arable land, coniferous forest and even mixed forests (Baum et.al. 2012). However, the ecological effects of SRC plantations are dependent on climate and soil conditions, the ecological preference of the cultivated maincrop species, rotation cycles, the species composition of the plantations, and the cultivation methods, including irrigation and nutrient supply and the degree of monoculture.

Undoubtedly, longer rotation cycles and greater biodiversity are ecologically beneficial, particularly in agroforestry systems and polycyclic arboriculture or in those short rotation plantations, where rotation cycles are long enough to allow newly established plant communities to develop a satisfactory level of biodiversity suitable for habitats, which may be able to recover after harvesting. The quality and value of wildlife habitats are influenced by the vegetation type, plant biodiversity and the invasive character of some plant species, the timing and frequency of the harvest and the stubble height after harvest and the impact of bioenergy crop cultivation on the character of the landscape (Némethy and Walas, 2016). The effect of Short Rotation Coppice systems on landscapeand regional-scale biodiversity will vary depending on the degree to which landscapes are already forested and the configuration of SRC plantations. In case of little existing shrub-dominated land, even smaller SRC plantations could enhance landscape-scale biodiversity. Cultivation of bioenergy crops may improve or create habitat for those species, that inhabit dense, shrubby vegetation. This may happen in marginal land areas of unsuitable forests, where the vegetation is replaced by dense bioenergy crops, which encourage the development of shrubby vegetative structures (shrubs and saplings) through biomass harvests (clear-cutting and thinning).

Sustainable game management and forestry actively contributes to maintaining biodiversity. In natural areas where intensive wildlife management is practiced, it is important to maintain the natural ecosystem. Wildlife needs a natural habitat, a feeding, hiding and breeding ground. Therefore, game management can only be successful where these conditions are provided to the wildlife. This means that large areas of forests, diverse habitats with natural waters and sheltered areas, where free-moving wildlife can be maintained, should be preserved for this purpose. In traditional forestry and even in sustainable, organic cultivation of woody bioenergy crops such as longer rotation cycle plantations, agroforestry and polycyclic arboriculture high energy crops, free of agrochemicals, provide an abundant source of food for animals. In these areas, of course, not only the wildlife to be exploited can find optimal living conditions, but every living creature that makes up the ecosystem (Fig 4). Such carefully managed hunting areas have much greater biodiversity. The number of species and the number of individuals is noticeable. At the same time, soil 
life is enriched, which results in more vegetation. This in turn creates a new habitat for the entire ecosystem. When assessing the ecological viability of bioenergy crop cultivation, the relationships between biodiversity and ecosystem function (BEF) should be determined from the observed characteristics of aboveground - belowground multitrophic interactions, which may substantially improve the often far too mechanistic interpretation of BEF relationships.

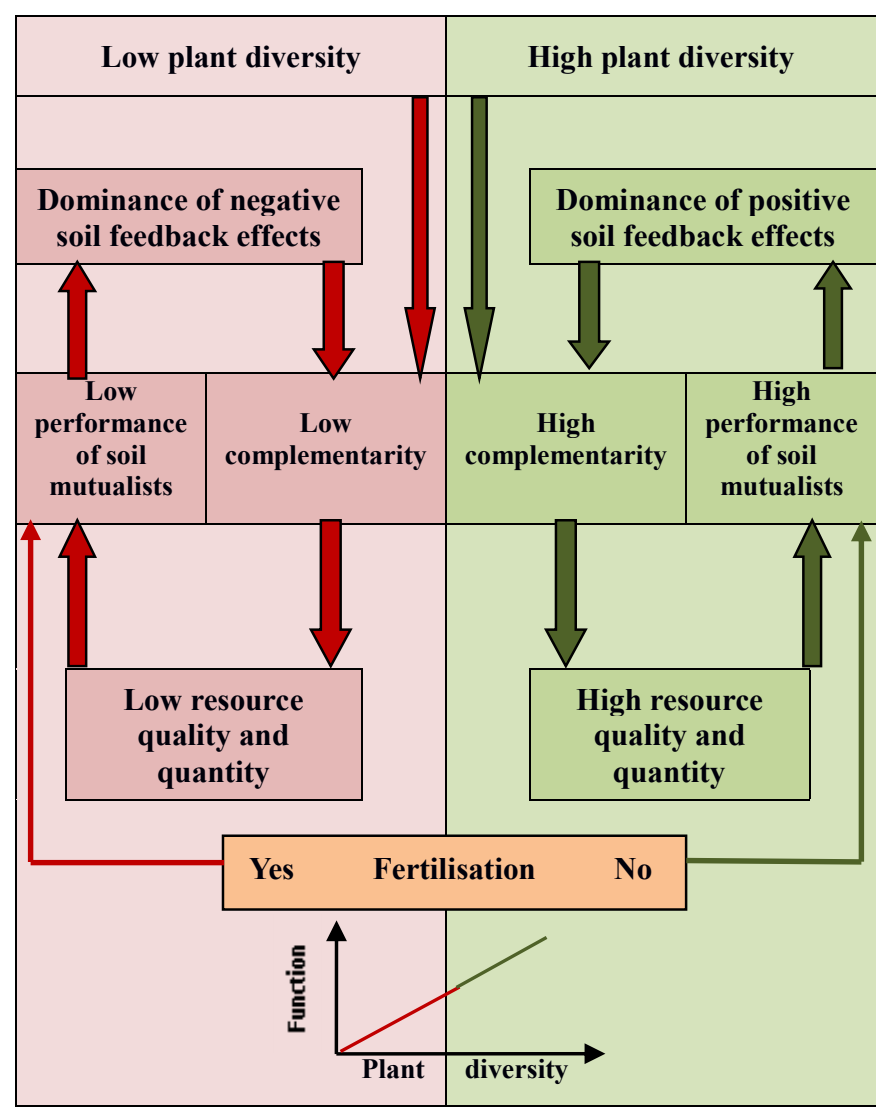

Figure 3. The influence of aboveground - belowground interactions on the positive relationship between biodiversity and ecosystem functioning. Resource use complementarity is higher in high communities with high plant diversity. Mutualists will mitigate or superimpose adverse effects of antagonists on plants (Eisenhauer, 2018, Latz et.al. 2012). Artificial fertilisation may have negative effect on the performance of soil mutualists, such as arbuscular mycorrhiza fungi (Collins Johnson, 1993). Source: redrawn and modified after Eisenhauer (2018).

Thus, the previously mentioned BEF-theory, which has been tested on willow SRC systems (Fig. 1), can be applied in connection with the analysis of the balance between negative and positive plant-soil feedback effects and the consequences for ecosystem functioning (Fig. 3). Research on the connection of biodiversity and plant biomass production showed, that plant community biomass was marginally significantly higher in species-rich plant communities than in species-poor ones suggesting varying net soil feedback effects depending on plant diversity (Eisenhauer, 2018).
The development of plant biodiversity in short rotation coppice is greatly influenced by light availability, which changes at every coppice rotation and the planted area evolves from a bare field to a shrubby vegetation, that later will become similar a forest with a closed canopy. These changes in the plant community determine the diversity of the fauna, such as bird populations, which evolve from open space to forest communities, continuously co-existing in shifting ratios. Arthropods and small mammals can satisfy their habitat needs from SRC while birds and large mammals only use the SRC for a limited number of resources. Hence, cultivation of bioenergy feedstocks could compensate for habitat losses for species that inhabit shrubby vegetation or regenerating forests (Tarr et.al. 2017). Furthermore, the previous use of land and the preceding vegetation cover may play an important role in the development of additional vegetation in the area of bioenergy plantations, since residual plants (seeds, roots, remaining stubbles, etc.) may develop new populations together with the newly established bioenergy plantations, contributing herewith to greater biodiversity and the development of more variable wildlife habitats.

Adverse environmental impacts of bioenergy production on agricultural fields can be minimized by low-input systems with diverse native species. Furthermore, following a complex system concept, in the vicinity of forested areas or woody biomass plantations, planting perennial grasslands for bioenergy feedstocks on low-quality agricultural land, currently dominated by agricultural crops, could increase the heterogeneity of these landscapes (Wiens et al., 2011).

From the above analyses it is obvious, that the value of wildlife habitats depends on the similarity of habitat properties to the natural, undisturbed state or the ability to develop sustainable, with the surrounding natural ecosystems compatible substitutions in cultivated areas. In case of cultivation of woody bioenergy feedstocks, the value of wildlife habitats depends on the cultivation factors, which include the type of the habitat, plant diversity, the invasive character of planted material (i.e. alien, invasive vs. native, non-invasive), the timing and frequency of harvest and disturbances, the ability of post-harvest recovery, habitat refugia as a function of the sizes of unharvested areas within the cultivated fields, the landscape content and the impact of cultivation methods on wildlife. Furthermore, plant biodiversity depends on the aboveground - belowground trophic interactions, which can be maintained only with sustainable, preferably with organic cultivation methods. Even if the biomass production is lower in ecologically managed systems, additional benefits (food, raw material for crafts, etc.) will compensate for these losses. 


\begin{tabular}{|c|c|c|}
\hline \multicolumn{3}{|c|}{ Wildlife Habitat Value } \\
\hline Lower & & Higher \\
\hline Cropland & Habitat type & Diverse native habitats \\
\hline Exotic monocultures & Plant diversity & Diverse native grasslands/forests \\
\hline Alien, invasive & Invasiveness of planted material & Native, non-invasive \\
\hline Breeding/nesting season & Harvest and disturbance timing & Late fall/early spring \\
\hline Multiple harvests in one year & $\begin{array}{l}\text { Harvest and disturbance } \\
\text { frequency }\end{array}$ & Single harvest in $\geq 1$ year \\
\hline Little/no remaining stubble & $\begin{array}{l}\text { Stubble height, post-harvest } \\
\text { plant architectural complexity }\end{array}$ & Tall stubble or regrowth \\
\hline $\begin{array}{l}\text { No unharvested area in field or } \\
\text { nearby }\end{array}$ & $\begin{array}{l}\text { Habitat refugia, formation of } \\
\text { connection corridors among } \\
\text { more natural but fragmented } \\
\text { habitat patches at least } \\
\text { temporally }\end{array}$ & harvested area within field \\
\hline Isolated patch/field & $\begin{array}{l}\text { Landscape Content } \\
\text { Wildlife Impact }\end{array}$ & of habitat patches/fields \\
\hline Higher & & Lower \\
\hline Native prairie/forest/wetland & Land use replaced with biomass crop & Marginal cropland \\
\hline High input & Use of fertilizers & Minimal input \\
\hline High input & Use of Pesticides & Minimal input \\
\hline Annual crops - high erosion & Soil Erosion and Sedimentation & nnial plants - low erosion \\
\hline Intensive monocultures & hytoremediation of Degraded Soils & Selected, mixed species \\
\hline
\end{tabular}

Figure 4. The value of wildlife habitats depending on the cultivation factors of bioenergy crops. For each factor, the qualities associated with greater wildlife benefit (or less impact) are listed on the right side of the figure, and the qualities that are associated with less wildlife benefit (or greater impact) are listed on the left side of the figure. The degree of plant architectural complexity: if higher, the habitat contains more strata, more and diverse branches, the wildlife is characterized by more microhabitats with higher chance for niche segregation, and more species; lower complexity results in habitats with simple layer, linear structures of wildlife, fewer microhabitats, and niches for fewer species (Source: modified after Fargione et.al. 2009) 


\section{Conclusions}

Bioenergy promises a number of regional and local development opportunities. Plants using bioenergy can benefit communities by being located close to feedstocks with electricity, heat and biogas being fed into the grid and biofuels being transported at least partially, as refined liquid fuel rather than bulky feedstocks. The feedstocks are in regional areas and consequently the jobs and economic activity, associated with their harvest, collection and transport, are and should remain regional or local. Bioenergy production could benefit regional and local development in a number of ways, some of which meet multiple goals such as:

- $\quad$ Reducing greenhouse gas emission such as biogas being captured and even deliberately produced and used to generate power or further refined for vehicle fuel (biomethane)

- Providing additional electricity for expansion of regional/local industry

- Using waste streams from agriculture and processing of agricultural products

- $\quad$ Providing options for land use in case of climate change

- Providing employment in regional/local areas.

It is important to keep in mind that woody biomass production has an impact on cultural landscapes, which are continuously changing due to natural processes and social factors. Therefore, rural development strategies should be applied in accordance with these changes. Trade-offs can almost always arise between different ecosystem services, such as the enhancement of provisioning services (e.g. economy of bioenergy feedstock plantations with longer rotation cycles instead of intensive coppicing) typically causes the decline in many other ecosystem services. Therefore, these trade-offs should be made transparently and equitably.

Linking woody bioenergy plantations and phytoremediation can greatly increase the sustainability of biomass production by improving soil and/or groundwater quality, removing hazardous substances from the environment, keeping biomass production in those areas, which are less suited for food production.

In woody biomass production longer rotation cycles and greater biodiversity are particularly beneficial in agroforestry systems and polycyclic arboriculture or in those short rotation plantations, where the length of rotation cycles allows newly established plant communities to develop a satisfactory level of biodiversity suitable for habitats.

When assessing the impact of bioenergy crop production of wildlife habitats taking into consideration the demand for bioenergy, the following factors are the most important:

- estimating gains and/or losses in the number of habitats for individual species at the landscape scale, based on sufficiently large demand of bioenergy on realistic levels

- the effect of different bioenergy portfolios on wildlife habitats;

- connections between specific sources of biomass and individual species;
- possibilities for ecocycle-based organic bioenergy feedstock production in SRC systems (e.g. irrigation of woody bioenergy crops with purified wastewater) linked to conservation of habitats;

- connections of natural ecosystems and artificial ecosystems created by bioenergy crop cultivation: enlarging suitable habitats and increasing habitat complexity - great potential in ecological networks.

- $\quad$ potential in greening agriculture.

The investigation of these factors should provide information for constructing future strategies of bioenergy systems with particular emphasis on the impact on wildlife habitats and create feedstock portfolios that support sustainable wildlife populations (Tarr et.al. 2017).

$$
* * *
$$

\section{References}

Albaugh, J.M., Dye, P.J. and King, J.S. (2013): Eucalyptus and Water Use in South Africa. International Journal of Forestry Research, Volume 2013, Article ID 852540, 11 pages, http://dx.doi.org/10.1155/2013/852540

Baum, S., Bolte, A. and Weih, M. (2012): Short Rotation Coppice (SRC) Plantations Provide Additional Habitats for Vascular Plant Species in Agricultural Mosaic Landscapes. Bioenerg. Res. (2012) 5: 573.

https://doi.org/10.1007/s12155-012-9195-1

Binkley, D. and Stape, J.L. (2004): Sustainable management of Eucalyptus plantations in a changing world In: $N$. Borralho, J. S. Pereira, C. Marques, J. Coutinho, M. Madeira, and M. Tomé, Eds): Proceedings of the IUFRO Conference of Eucalyptus in a Changing World, pp. 11-17, Aveiro, Portugal, October 2004.

Brown, M. E. and Funk, C. C., (2008): Food Security Under Climate Change NASA Publications. 131.

http://digitalcommons.unl.edu/nasapub/131

Christersson, L. (2005): Plant physiological aspects of woody biomass production for energy purposes. In K.S. Verma, D.K. Khurana \& L. Christersson, eds. Short rotation forestry for industrial and rural development. Nauni, Solan, Himachal Pradesh, India, Indian Society of Tree Scientists.

Collins Johnson, N. (1993): Can Fertilization of Soil Select Less Mutualistic Mycorrhizae? Ecological Applications

Vol. 3, No. 4 (Nov., 1993), pp. 749-757

https://doi.org/10.2307/1942106

Cooper, P.J.M., Leakey, R.R.B., Rao, M.R. and Reynolds L. (1996): Agroforestry and the mitigation of land depletion in the humid and sub-humid tropics of Africa. Experimental Agriculture, 32. pp. 235-290.

https://doi.org/10.1017/S0014479700026223 
Dimitriou, I. and Aronsson, P. (2004): Nitrogen leaching from Short-Rotation Willow Coppice after intensive irrigation with wastewater. Biomass and bioenergy; 26(5), pp. 433-441 https://doi.org/10.1016/j.biombioe.2003.08.009

Echereme, C.B., Igboabuchi, N.A., Izundu, A.I. (2018): Phytoremediation of Heavy Metals and Persistent Organic Pollutants (POPs): A Review. Ijsrm. Human, 2018; Vol. 10 (4) pp. 107-125. www.ijsrm.humanjournals.com

Eckerle, K.P., Thompson, C.F. (2001) Yellow-breasted chat (Icteria virens). In: The Birds of North America Online (ed. Poole A), Cornell Lab of Ornithology, Ithaca. Available at: http://bna.birds.cornell.edu/bna/species/575

Eisenhauer, N. (2018): Aboveground-belowground interactions drive the relationship between plant diversity and ecosystem function. Research Ideas and Outcomes, 4:e23688. https://doi.org/10.3897/rio.4.e23688

Faaij A.P.C. (2006): Modern biomass conversion technologies. Mitig. Adapt. Strat. Global Change. 11, pp. 335-367. https://doi.org/10.1007/s11027-005-9004-7

Facciotto, G., Minotta, G., Paris, P. and Pelleri, F. (2014): Tree farming, Agroforestry and the New Green Revolution. A necessary alliance. Proceeding of the II International Congress of Silviculture: Designing the future of the forestry sector; Florence, Volume: 2

http://dx.doi.org/10.4129/2cis-gf-tre

Fargione, J.E., Cooper, T.R., Flashpohler, D.J., Hill, J., Lehman, C., McCoy, T., McLeod, S., Nelson, E.J., Oberhauser, K.S. and Tilman, D. (2009): Bioenergy and Wildlife: Threats and Opportunities for Grassland Conservation. BioScience, Vol. 59 No. 9. pp. 767-777

https://doi.org/10.1525/bio.2009.59.9.8

Gomes, H.I. (2012): Phytoremediation for bioenergy: challenges and opportunities. Environmental Technology Reviews, http://dx.doi.org/10.1080/09593330.2012.696715

Gyulai. G., Bittsánszky, A., Szabó, Z., Waters, L. Jr., Gullner, G., Kampfl, G., Heltai, G. and Komíves, T. (2014): Phytoextraction potential of wild type and 35S-gshI transgenic poplar trees (Populus $\mathrm{x}$ Canescens) for environmental pollutants herbicide paraquat, salt sodium, zinc sulfate and nitric oxide in vitro.

https://doi.org/10.1080/15226514.2013.783553

Gupta, N., Khan, D.K., Santra, S.C. (2009). Prevalence of intestinal helminth eggs on vegetables grown in wastewaterirrigated areas of Titagarh, West Bengal, India. Food Control 20, pp. 942-945.

https://doi.org/10.1016/j.foodcont.2009.02.003

Hamelinck C.N, Suurs R.A.A, Faaij A.P.C. (2004): Technoeconomic analysis of international bio-energy trade chains. Biomass Bioenergy. 29, pp. 114-134. https://doi.org/10.1016/j.biombioe.2005.04.002
Hartel, T., J. Fischer, C. Campianu, A. Milcu, J. Hanspach, and I. Fazey (2014): The importance of ecosystem services for rural inhabitants in a changing cultural landscape in Romania. Ecology and Society 19(2): 42.

http://dx.doi.org/10.5751/ES-06333-190242

International Energy Agency (2018): Renewables 2018 analysis and forecasts to 2023. p. 211. France.

https://www.iea.org/renewables2018/

Latz, E., Eisenhauer, N., Rall, B., Allan, E., Roscher, C., Scheu, S. and Jousset, A. (2012): Plant diversity improves protection against soil-borne pathogens by fostering antagonistic bacterial communities. Journal of Ecology 100 (3), pp. 597-604.

https://doi.org/10.1111/j.1365-2745.2011.01940.x

Leakey, R.R.B. (2017): Definition of agroforestry revisited. In book: Multifunctional Agriculture - Achieving Sustainable Development in AfricaEdition: 1. Chapter: 1. Definition of agroforestry revisited. Publisher: Academic Press, California https://doi.org/10.1016/B978-0-12-805356-0.00001-5

McCalmont JP, Hastings A, McNamara NP, Richter GM, Robson P, Donnison IS, Clifton-Brown J. (2017): Environmental costs and benefits of growing Miscanthus for bioenergy in the UK. Glob Change Biol Bioenergy. 2017 Mar; 9(3): 489-507. Epub 2015 Aug 18. Review. https://doi.org/10.1111/gcbb.12294 PMID: 28331551

Merino, I., Campos, V.M., Casado, R., Pacios, L.F. and Gomez, L. (2008): Review. Phytoremediation of organic pollutants. Spanish Journal of Agricultural Research, 6(S1):38. https://doi.org/10.5424/sjar/200806S1-372

Némethy, S. \& Wałas, B. (2016): Bioenergy crops as new components of rural and agricultural landscapes: environmental and social impact, conservation, cultural heritage and economy. Journal of Central European Green Innovation, (JCEGI 3(TI)) HU ISSN 2064-3004, Hungary

Némethy, S. (2018): Bioenergetics in the context of society, economy and environment (In Hungarian) Hungarian Science, Journal of the Hungarian Academy of Sciences. HU ISSN $0025 \quad 0325 . \quad 179(2018) 8$, pp. 1232-1243. https://doi.org/10.1556/2065.179.2018.8.12

Némethy, S. (2019): The importance of mineral-based soil improvement substances in viticulture. In Hungarian. Értékálló Aranykorona (Valuable Golden Crown, national agricultural magazine), 19. 3. pp. 16-18. ISSN: 1586-9652 (Ref: MATARKA)

Oelbermann M, Voroney R.P, Gordon A.M. (2004): Carbon sequestration in tropical and temperate agroforestry systems: a review with examples from Costa Rica and southern Canada. Agric. Ecosyst. Environ. 104, pp. 359-377. https://doi.org/10.1016/j.agee.2004.04.001 
Pacheco, P., Wardell, A., German, L., Johnson, F.X., Neil, B., van Gelder, J.W., Schwaiger, H.P., Schoneweld, G.C., Obidzinski, K., Guariguata, M. R. (2012): Synthesis: Bioenergy, Sustainability and Trade-offs: Can we Avoid Deforestation while Promoting Biofuels? CIFOR Infobriefs, No. 54, October 2012. www.cifor.org ;

https://doi.org/10.17528/cifor/003914

Panoras, A., Zdragas, A., Ilias, A., Anagnostopoulos, K. (1998) Microbiological quality criteria for municipal wastewater reuse in agriculture. Geotechnical Scientific Issues, v. 9, No. 31/1998, pp. 90-103, Thessaloniki, Greece.

Panoras, A., Evgenidis, G., Bladenopoulou, S., Melidis, V., Doitsinis, A., Samaras, I., Zdragkas, A. and Matsi, Th. (2003): Corn irrigation with reclaimed municipal wastewater. Selected from papers presented at the 7th Conference on Environmental Science and Technology, 3 - 6 September 2001, Ermoupolis, Syros island, Greece. Global Nest: The Int. J. Vol 5, No 1, pp. 39-45, 2003

Perttu, K. \& Obarska-Pempkowiak, H., eds. (1998): Sewage treatment by means of pine, willow, reed and grass vegetation filters. Proceedings of a joint Polish-Swedish workshop in Starbienino, Poland, 25-28 May 1997. Department of Short Rotation Forestry, Report No. 61. Uppsala, Sweden, SLU. http://www.slu.se/en/library/

Qadir, M., Wichelns, D., Raschid-Sally, L., McCornick, P. G., P. Drechsel, P., Bahri, A., Minhas, P. S. (2010). The challenges of wastewater irrigation in developing countries. Agricultural Water Management 97. pp. 561-568. http://digitalcommons.unl.edu/wffdocs

Rupp, S. P., L. Bies, A. Glaser, C. Kowaleski, T. McCoy, T. Rentz, S. Riffell, J. Sibbing, J. Verschuyl, and T. Wigley (2012): Effects of bioenergy production on wildlife and wildlife habitat. Wildlife Society Technical Review 12-03. The Wildlife Society, Bethesda, Maryland, USA. ISBN: 978-09830402-2-4. www.wildlife.org/publications/technicalreviews

Shukla, O.P., Juwarkar, A.A., Singh, S.K., Khan, S., Rai, U.N. (2011): Growth responses and metal accumulation capabilities of woody plants during the phytoremediation of tannery sludge. Waste Management; Volume 31, Issue 1, January 2011, pp. 115-123.

https://doi.org/10.1016/j.wasman.2010.08.022

Smeets, E.M.W., Faaij A.P.C., Lewandowski I.M., Turkenburg W.C. (2007): A bottom up quick scan and review of global bio-energy potentials to 2050. Prog. Energy Combust. Sci. 33, 56-106. 329, pp. 790-792.

Sovacool, B.K. and Murkherjee, I. (2011): Conceptualizing and measuring energy security: A synthesized approach. Energy, Volume 36, Issue 8, August 2011, pp. 5343-5355 https://doi.org/10.1016/j.energy.2011.06.043

Sun, W.H., Lo, J.B., Robert, F.M., Chittaranjan R., ChungShih Tang (2004): Phytoremediation of petroleum hydrocarbons in tropical coastal soils I. selection of promising woody plants. Environ Sci \& Pollut Res (2004) 11: 260. https://doi.org/10.1007/BF02979634

Stape, J.L., Gonçalves, J.L.M., and Gonçalves, A.N. (2001): Relationships between nursery practices and field performance for Eucalyptus plantations in Brazil. New Forests, vol. 22, pp. 19-41, 2001 - Springer.

https://doi.org/10.1023/A:1012271616115

Tarr, N.M., Rubino, M.J., Costanza, J.K., McKerrow, A.J., Collazo, J.A., Abt, R.C. (2017): Projected gains and losses of wildlife habitat from bioenergy-induced landscape change. GCB Bioenergy (2017) 9, pp. 909-923, https://doi.org/10.1111/gcbb.12383

Vanbeveren, S.P.P. and Ceulemans, R. (2019): Biodiversity in short-rotation coppice. Renewable and Sustainable Energy Reviews 111. pp. 34-43.

https://doi.org/10.1016/j.rser.2019.05.012

Vermeulen, S.J., Aggarwal, P.K., Ainslie, A., Angelone, C., Campbell, B.M., Challinor, A.J., Hansen, J.W., Ingram, J.S.I., Jarvis, A., Kristjanson, P., Lau, C., Nelson, G.C., Thornton, P.K., Wollenberg, E. (2012): Options for support to agriculture and food security under climate change. Environmental Science \& Policy Volume 15, Issue 1, January 2012, pp. 136-144

https://doi.org/10.1016/j.envsci.2011.09.003

Watanabe, M. (1997): Phytoremediation on the bank of commercialization. Environmental Science and Technology, 31(4): 182A-186A https://doi.org/10.1021/es972219s

Weih, M., Glynn, C. and Baum, C. (2019): Willow ShortRotation Coppice as Model System for Exploring Ecological Theory on Biodiversity-Ecosystem Function. Diversity 2019, 11(8), 125; https://doi.org/10.3390/d11080125

Wiens, J., Fargione, J., Hill, J. (2011) Biofuels and biodiversity. Ecological Applications, 21, pp. 1085-1095. https://doi.org/10.1890/09-0673.1 